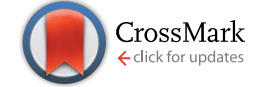

Cite this: RSC Adv., 2014, 4, 56003

Received 13th July 2014

Accepted 23rd October 2014

DOI: $10.1039 / c 4 r a 07045 c$

www.rsc.org/advances

\title{
Efficient synthesis of pyrene-1-carbothioamides and carboxamides. Tunable solid-state fluorescence of pyrene-1-carboxamides $\uparrow$
}

\author{
Anna Wrona-Piotrowicz, ${ }^{a}$ Janusz Zakrzewski, ${ }^{* a}$ Rémi Métivier, ${ }^{\text {tb }}$ Arnaud Brosseau, ${ }^{\text {b }}$ \\ Anna Makal ${ }^{\mathrm{C}}$ and Krzysztof Woźniak ${ }^{\mathrm{C}}$ \\ Pyrene reacts with potassium thiocyanate and organic isothiocyanates in the presence of \\ trifluoromethanesulfonic acid to afford primary and secondary pyrene-1-carbothioamides in high yields. \\ These compounds were efficiently oxidatively desulfurized with Oxone® to the corresponding \\ carboxamides. The amides display solid-state fluorescence with quantum efficiencies up to $62 \%$, \\ originating from monomers, aggregates (such as preformed dimers), and/or excimers, depending on the \\ substituent at the nitrogen atom. Single crystal X-ray diffraction characterization of one highly emissive \\ compound supports this assumption.
}

\section{Introduction}

Pyrene derivatives have attracted significant interest as materials for organic electronics, ${ }^{1}$ fluorescent molecular probes, ${ }^{2-4}$ monomers, ${ }^{5}$ triplet sensitizers ${ }^{6}$ and sensors. ${ }^{3,7-9}$ Considerable attention has been paid to the development of synthetic routes to pyrenes bearing various substituents ${ }^{\mathbf{1 1 0 , 1 1}}$ and to studies on their fluorescence properties. ${ }^{11-13}$

Several recent works have focused on environmentallyresponsive emission of pyrene-1-carboxamides which is strongly dependent on the substituents at the nitrogen atom. ${ }^{12,14-16}$ Moreover, these compounds were used in the synthesis of polymers with tunable luminescent properties ${ }^{17}$ and in the labelling of nucleosides. ${ }^{7,8,18-22}$

In contrast to amides, pyrene-1-carbothioamides are only weakly fluorescent ${ }^{23,24}$ because of the internal quenching effect of the thiocarbonyl group. Since some chemical species desulfurize thioamides (e.g. Oxone ${ }^{\circledR}, \mathrm{H}_{2} \mathrm{O}_{2}$ in the presence of $\left.\mathrm{Zr}^{4+}\right)$ to fluorescent amides, pyrene thioamides were used as fluorescent "turn-on" sensors of such species ${ }^{23,24}$.

The reported synthetic route to pyrene-1-carboxamides relies on the reaction of pyrene-1-carboxylic acid chloride with amines. The amides can then be transformed into thioamides via a reaction with Lawesson reagent. ${ }^{17,23,24}$

\footnotetext{
${ }^{a}$ Department of Organic Chemistry, Faculty of Chemistry, University of Łódź, Tamka 12, 91-403 Łódź, Poland. E-mail: janzak@uni.lodz.pl

${ }^{b} P P S M$, ENS Cachan, CNRS, UniverSud, 61 av President Wilson, 94230 Cachan, France.E-mail:metivier@ppsm.ens-cachan.fr

${ }^{c}$ Faculty of Chemistry, Warsaw University, Pasteura 1, 02-093 Warszawa, Poland

$\dagger$ Electronic supplementary information (ESI) available. CCDC 1006140. For ESI and crystallographic data in CIF or other electronic format see DOI: $10.1039 / \mathrm{c} 4 \mathrm{ra} 07045 \mathrm{c}$
}

In this paper we report an efficient method of synthesis of primary and secondary pyrene-1-carbothioamides directly from pyrene via a Friedel-Crafts-type reaction with potassium thiocyanate and organic isothiocyanates, respectively. The thioamides were then desulfurized into the corresponding amides using Oxone®. Furthermore, we discovered that most of the synthesized amides are fluorescent not only in solution, as was reported earlier, but also in the solid state. Solid-state emission is a phenomenon of great practical importance, ${ }^{25-27}$ but is relatively rare in the case of planar aromatic compounds such as pyrene and its derivatives. We found that the solid-state emissive properties of synthesized pyrene-1-carboxamides strongly depend on the substituent on the nitrogen atom and for bulky substituents fluorescence quantum yields as high as $60 \%$ were obtained.

\section{Results and discussion}

A Friedel-Crafts-type reaction of organic isothiocyanates with aromatic compounds is a straightforward synthetic route to secondary thioamides. ${ }^{28-31}$ We recently reported that a reaction of pyrene with ethoxycarbonylisothiocyanate afforded $\mathrm{N}$ ethoxycarbonyl-pyrene-1-carbothioamide in $95 \%$ yield. ${ }^{32}$ Primary thioamides were obtained in a reaction of electron-rich arenes (1,2-diethoxybenzene, ferrocene) with potassium thiocyanate in methanesulfonic acid. ${ }^{28,33,34}$

Herein we report that pyrene reacts with potassium thiocyanate in the presence of 4 equiv. of TfOH to afford the primary thioamide 1a in $63 \%$ yield (Scheme 1). The reaction was performed in dichloromethane at room temperature. Under the same conditions, reaction of pyrene with alkyl- and aryl isothiocyanates afforded secondary thioamides $\mathbf{1 b}-\mathbf{j}$ in $78-96 \%$ yield. Thioamides $\mathbf{1 a}-\mathbf{j}$ were conveniently isolated, after 


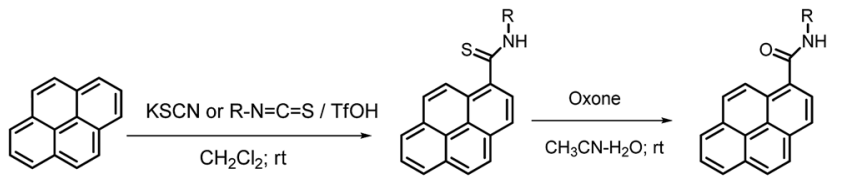

$1 a-j$

2a-j

\begin{tabular}{|c|c|c|}
\hline \multirow{2}{*}{$\mathrm{R}$} & \multicolumn{2}{|c|}{ Yield (\%) } \\
\cline { 2 - 3 } & $\mathbf{1}$ & $\mathbf{2}$ \\
\hline $\mathrm{H}(\mathbf{a})$ & 63 & 86 \\
\hline iso-Pr (b) & 96 & 95 \\
\hline tert-Bu (c)) & 93 & 93 \\
\hline $\mathrm{n}$-hexyl (d) & 91 & 96 \\
\hline cyclohexyl (e) & 94 & 91 \\
\hline $\mathrm{Bz}(\mathbf{f})$ & 78 & 89 \\
\hline $\mathrm{Ph}(\mathbf{g})$ & 85 & 92 \\
\hline $\mathrm{Bn}$ (h) & 86 & 90 \\
\hline$p-\mathrm{MeO}-\mathrm{Ph}(\mathbf{i})$ & 88 & 90 \\
\hline$p-\mathrm{NO}_{2}-\mathrm{Ph}(\mathbf{j})$ & 87 & 79 \\
\hline
\end{tabular}

Scheme 1 Synthesis of thioamides $1 \mathrm{a}-\mathrm{j}$ and amides $2 \mathrm{a}-\mathrm{j}$.

quenching the reaction mixtures with water and extraction, via column chromatography on silica gel.

After having elaborated an efficient direct method for thioamidation of pyrene, we explored the possibility of extending this method to the synthesis of pyrenyl amides using isocyanates instead of isothiocyanates. We chose the reaction of pyrene with phenyl isocyanate as a model. Unfortunately, we found that this reaction provided the expected $N$-phenylpyrene-1carboxamide only in low $(\sim 30 \%)$ yield. Because of this unsatisfactory result, we changed our approach in order to find another synthetic route to pyrenyl amides.

Since a variety of simple and efficient methods of desulfurization of thioamides to amides has been reported in the literature, ${ }^{35}$ we decided to check whether this transformation could be applied to the synthesis of pyrenyl amides.

We decided to use a commercially available and inexpensive oxidant, Oxone ${ }^{\circledR}\left(2 \mathrm{KHSO}_{5} \cdot \mathrm{KHSO}_{4} \cdot \mathrm{K}_{2} \mathrm{SO}_{4}\right)$, for the desulfurization of thioamides $\mathbf{1} \mathbf{a}-\mathbf{j}$. This reagent has already been used for desulfurization of other thioamides..$^{14,15,36,37}$ Furthermore, the reaction of Oxone ${ }^{\circledR}$ with $N, N$-diethyl-1-pyrene-carboxamide was applied for fluorescence sensing of this oxidant. ${ }^{24}$

We found that Oxone® reacts smoothly with thioamides 1a-j in acetonitrile-water at room temperature to afford the corresponding amides $2 \mathbf{2}-\mathbf{j}$ in high yields $(86-100 \%$, Scheme 1 ).

In order to complete the series for photophysical studies, we also synthesized pyrene amides $\mathbf{2 k - \mathbf { m }}$ bearing bulky substituents at the nitrogen atom (Scheme 2). Since the isothiocyanates required for syntheses of these compounds via Friedel-Crafts reaction were not available we prepared them from pyrene-1carboxylic acid and the corresponding amines in the presence of $N, N^{\prime}$-dicyclohexylcarbodiimide (DCC). The isolated yields of $2 \mathbf{k}-\mathbf{m}$ were in the range of $85-90 \%$.

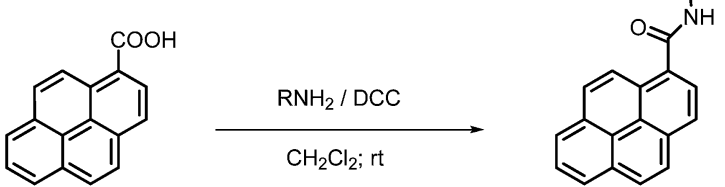

2k R = 1-adamantyl (85\%) 2l R $=\mathrm{CHPh}_{2}(90 \%)$ $2 \mathrm{~m} \mathrm{R}=\mathrm{CPh}_{3}(86 \%)$

Scheme 2 Synthesis of pyrene-1-carboxamides $2 \mathrm{k}-\mathrm{m}$.

All synthesized compounds were fully characterized by spectroscopic methods and elemental analyses.

\section{Solid-state fluorescence of pyrene-1-carboxamides $2 \mathrm{a}-\mathbf{m}$}

Solution fluorescence of various pyrene-1-carboxamides was recently thoroughly studied by Konishi et al. ${ }^{14-16}$ During the course of our synthetic work, we discovered that these compounds are also solid-state emitters. Organic solid-state fluorescence is of great interest currently because of its relevance to numerous practical applications, e.g. in organic lightemitting diodes, organic light-emitting field-effect transistors, solid-state lasers and sensors. ${ }^{25-27}$ It critically depends on interactions of molecular fluorophores $(\pi-\pi$ interactions, formation of $\mathrm{H}-$ or J-aggregates, excimers, etc.) in powders, crystals or solid films. ${ }^{38}$

We measured solid-state excitation spectra, emission spectra and fluorescence quantum yields of amides $2 \mathbf{a}-\mathbf{d}, \mathbf{g}, \mathbf{h}, \mathbf{k}-\mathbf{m}$ (compound $2 \mathbf{j}$ proved non fluorescent). Corresponding spectra are displayed in Fig. 1 and spectroscopic data are gathered in Table 1.

It is visible in Table 1 that substituents at the nitrogen atom strongly influence solid-state emissive properties of the synthesized amides. On one side, the primary amide 2a shows a weak structured violet fluorescence $\left(\Phi_{\mathrm{F}}=6 \%\right)$, that is similar in shape to its fluorescence spectrum when dissolved in chloroform (Fig. 2A). However, compared to the solution spectrum, the solid-state emission spectrum of $2 \mathrm{a}$ is red-shifted by $25 \mathrm{~nm}$, and a long tail can be observed at wavelengths over $450 \mathrm{~nm}$. This observation suggests that the interaction of fluorophores influencing solid-state fluorescence is in this case rather limited. On the other side, the solid-state excitation/emission spectra of the secondary amides have a wide variety of shapes, with corresponding quantum efficiencies varying from $0.2 \%$ to $62 \%$, as a function of the substituents. When analyzing in detail the solid-state emission spectra, we can distinguish several cases: (i) one compound (2g) shows a clear monomer contribution, peaking at $414 \mathrm{~nm}$, associated with a structured shape and a very low fluorescence quantum yield $\left(\Phi_{\mathrm{F}}=0.2 \%\right)$; (ii) several compounds (2b-c, $2 \mathbf{k}-\mathbf{m})$ display a large red-shifted single band, with quantum yields in the $7-62 \%$ range; and (iii) two compounds ( $2 \mathbf{d}$ and $\mathbf{2 h}$ ) show a well-apparent shoulder at the violet edge of the spectrum (406-416 nm) and a main emission band in the range of $450-600 \mathrm{~nm}$, with intermediate 


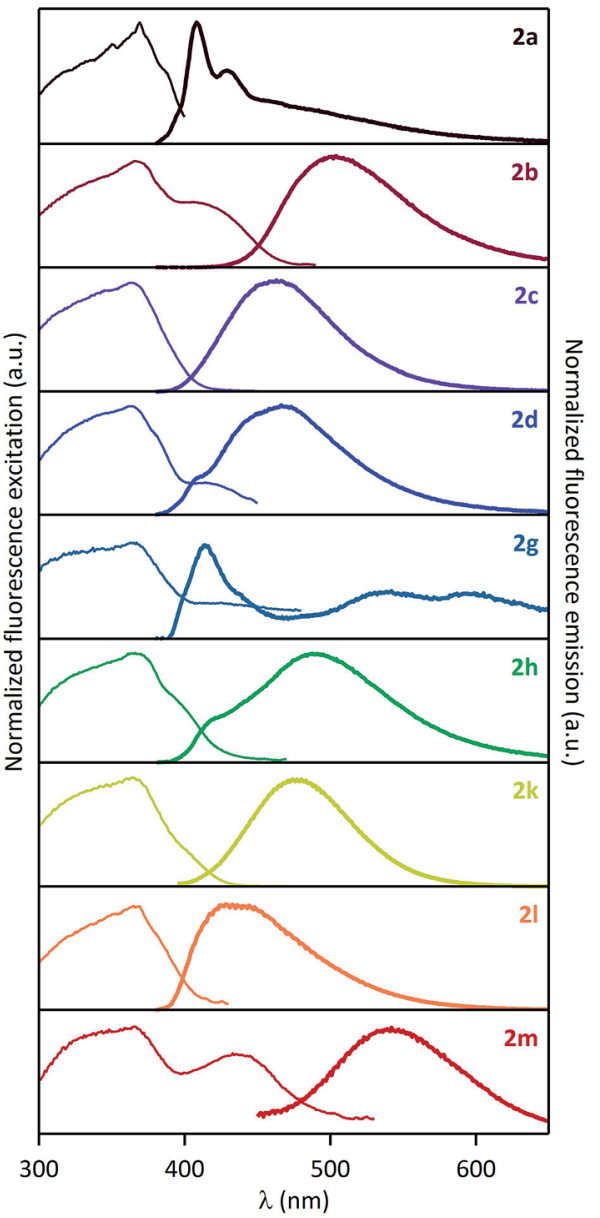

Fig. 1 Normalized solid-state excitation (left) and emission (right) spectra of pyrene-1-carboxamides $2 a-d, g, h, k-m$.

Table 1 Solid-state absorption and emission data of pyrene-1-carboxamides $2 \mathrm{a}-\mathrm{d}, \mathrm{g}, \mathrm{h}, \mathrm{k}-\mathrm{m}$

\begin{tabular}{lllc}
\hline Amide & Excitation $^{a} \lambda_{\text {max }} / \mathrm{nm}$ & Emission $^{a} \lambda_{\text {max }} / \mathrm{nm}$ & $\Phi_{\mathrm{F}} / \%$ \\
\hline 2a $(\mathrm{R}=\mathrm{H})$ & 369 & 408,430 & 6 \\
2b $(\mathrm{R}=$ iso-Pr $)$ & $367,410(\mathrm{sh})$ & 504 & 17 \\
2c $(\mathrm{R}=t$ - $\mathrm{Bu})$ & 364 & 463 & 59 \\
2d $(\mathrm{R}=n$-hexyl) & $363,415(\mathrm{sh})$ & $406(\mathrm{sh}), 466$ & 12 \\
2 $(\mathrm{R}=\mathrm{Cy})$ & 367 & 414 & 0.2 \\
2h $(\mathrm{R}=\mathrm{Bn})$ & $366,400(\mathrm{sh})$ & $416(\mathrm{sh}), 488$ & 20 \\
2k $(\mathrm{R}=1$-adamantyl) & 364 & 477 & 62 \\
2l $\left(\mathrm{R}=\mathrm{CHPh}_{2}\right)$ & 365 & 428 & 12 \\
2m $\left(\mathrm{R}=\mathrm{CPh}_{3}\right)$ & 365,433 & 542 & 7
\end{tabular}

${ }^{a}$ Shoulders are noted (sh).

quantum yields ( $12 \%$ and $20 \%$, respectively). The spectral signatures highlighted in the two latter cases are clear indications that the solid-state emission originates from aggregates such as preformed dimers, or excimers. Moreover, the excitation spectra depicted in Fig. 1 all show a main maximum band around 363-369 $\mathrm{nm}$, but also eventually a shoulder (or even a well-defined separated band) at longer wavelengths, in the range of 400-433 $\mathrm{nm}$ (amides $2 \mathbf{b}, \mathbf{2 d}, \mathbf{2 h}, \mathbf{2 l}$, see Table 1). This
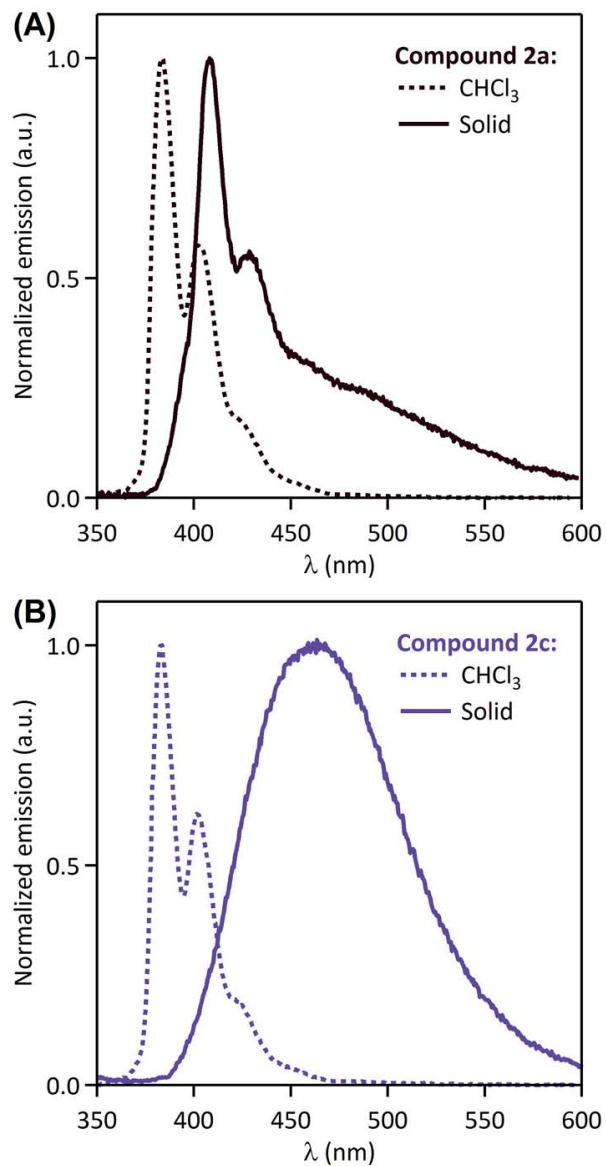

Fig. 2 Normalized solution $\left(\mathrm{CHCl}_{3}\right)$ and solid-state fluorescence emission spectra of $2 a(A)$ and $2 c(B)$.

observation supports the presence of aggregates in the ground state. In spite of this variety of fluorescence properties, a general tendency can be drawn i.e. that: the increase of the size of the alkyl substituent at the nitrogen atom brings about an increase in the fluorescence quantum yield. Indeed, the amides $2 \mathbf{c}$ and $2 \mathbf{j}$ bearing a bulky $N$-tert-butyl and 1-adamantyl groups are the most efficient solid-state emitters of the series $\left(\Phi_{\mathrm{F}}=59 \%\right.$ and $62 \%$, respectively). On the other hand, $N$-phenyl substitution (compound $\mathbf{2 g}$ ) leads practically to disappearance of the solidstate emissive properties. The $N$-benzyl amide $2 \mathbf{h}$ shows moderate fluorescence quantum yield (20\%) and the attachment of the second and third phenyl ring to the sp3 carbon (amides $\mathbf{2 l}$ and $\mathbf{2 m}$, respectively) brings about decrease of the fluorescence quantum yield.

Practically, the colors of solid-state fluorescence emitted by the investigated series of amides are shown in the CIE diagram (Fig. 3). As a consequence of the different fluorescence spectral shapes of these pyrene derivatives, the solid-state emission expands over a wide range of colors, from violet-blue to green and even yellow, depending on the substituents.

It is worth noting that the most efficient compounds (2c and 2j) emit in the blue region. Interestingly, the former compound has co-ordinates close to those required for deep-blue emission $(y<0.15 ; x+y<0.30, c f$. ESI $\dagger) .{ }^{39}$ The substituents at the nitrogen 


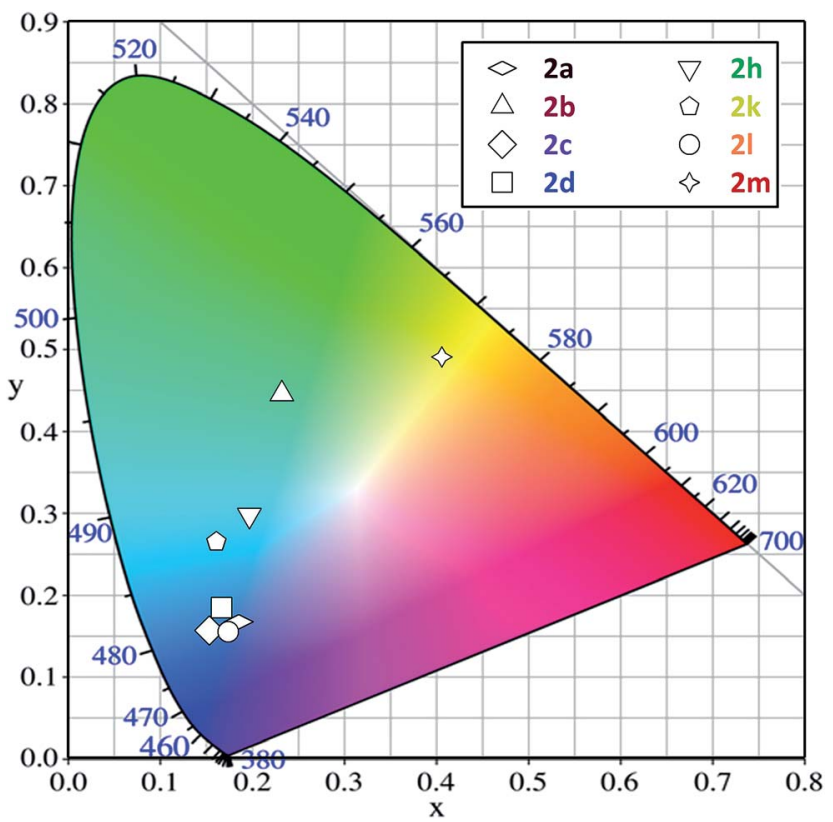

Fig. 3 CIE chromacity diagram for compounds $2 a-d, h, k-m$.

atom shift the fluorescence into the blue-green (compound $\mathbf{2 b}$ ) or even the green-yellow region (compound 2l). However, this bathochromic shift is accompanied by a decrease in emission efficiency.

In order to deepen our investigation of the photophysical properties of pyrene carboxamide derivatives in the solid-state, we recorded fluorescence decays for the whole series $\mathbf{2 a - d}, \mathbf{g}-\mathbf{h}$, $\mathbf{k}-\mathbf{m}$ at variable emission wavelengths. The time-correlated single photon counting (TCSPC) method was employed for short decays (decay time constants $<35 \mathrm{~ns}$ ), whereas the laser flash fluorometry was used for longer decays (including decay time constants $>35 \mathrm{~ns}$ ). The Fig. 4 displays the solid-state fluorescence decay curves of the compounds $\mathbf{2 a - d}, \mathbf{g}-\mathbf{h}, \mathbf{k}-\mathbf{m}$ recorded using these experimental methods, at their respective maximum emission wavelengths. In all cases, the fluorescence decays reveal a multiexponential behavior, which reflects the complexity of these systems in the solid-state. They were satisfactorily fitted with a sum of two, three or four exponentials, and the corresponding parameters are compiled in the Table 2. As was mentioned in the previous paragraph, the derivatives $\mathbf{2 a}$ and $2 \mathrm{~g}$ mostly show monomer emission, and constitute a first group of compounds. This translates into relatively short fluorescence decays, with time constants in the range of a few nanoseconds for $\mathbf{2 a}$, and even in the range of several hundreds of picoseconds for $2 \mathrm{~g}$. Thus, the different time constants may represent different populations of monomers in the solid. The time-resolved fluorescence investigations reveal a very specific situation for compounds $\mathbf{2 b}, \mathbf{2} \mathbf{d}$ and $\mathbf{2 h}$ (the second group of compounds). Indeed, they show a strong emission wavelength dependence of their fluorescence decays, as is highlighted in Fig. 5, with a multiexponential decay at short emission wavelength (recorded at the blue edge of the emission spectrum), and a short rise time followed by multiexponential decay at long
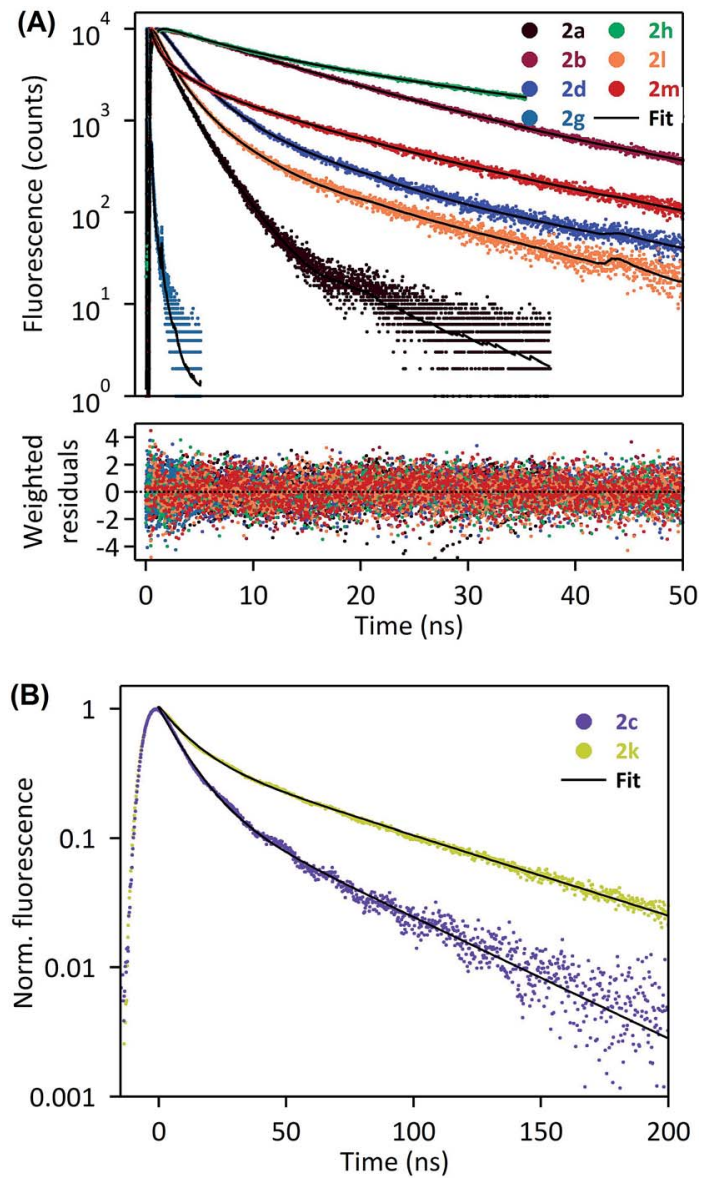

Fig. 4 Fluorescence decays of $2 \mathrm{a}, \mathrm{b}, \mathrm{d}, \mathrm{g}, \mathrm{h}, \mathrm{l}, \mathrm{m}$ in the solid state, recorded by the TCSPC system at $\lambda_{\text {exc }}=370 \mathrm{~nm}(\mathrm{~A})$, or laser flash fluorometry at $\lambda_{\text {exc }}=355 \mathrm{~nm}$ (B).

emission wavelength (recorded at the red edge of the emission spectrum). A global analysis was carried out on these data sets (see Table 2), which shows that the short rise time measured at long emission wavelength (0.3-1.6 ns) has the same order of magnitude as the shorter decay time recorded at short emission wavelength $(0.5-0.7 \mathrm{~ns})$. This finding may be consistent with the dynamics of fast excimer formation in the solid-state, and is rather compatible with the spectral features described in the previous paragraph. In this frame the longest decay time constant, determined for $\mathbf{2 b}, \mathbf{2 d}$ and $2 \mathbf{h}$ to be $23.7 \mathrm{~ns}, 24.8 \mathrm{~ns}$, and $34.1 \mathrm{~ns}$, respectively, corresponds specifically to excimer emission, since its relative fraction of intensity increases at longer emission wavelength (Table 2). Then the last group of four compounds, namely $2 \mathbf{c}$ and $\mathbf{2 j} \mathbf{j} \mathbf{- 1}$, exhibits intermediate behavior between purely monomeric emission (such as $2 \mathbf{a}$ and $\mathbf{2 g}$ ) and well-defined excimer formation (such as $\mathbf{2 b}, \mathbf{2 d}$ and $\mathbf{2 h}$ ). On the one hand, the $\mathbf{2} \mathbf{c}$ and $\mathbf{2 k} \mathbf{k}-\mathbf{m}$ derivatives do not show any rise time at long wavelength emission, which excludes the excimer formation mechanism in these cases. On the other hand, their fluorescence decays are rather long and their emission spectra are broad, red-shifted, without any vibrational structure, which is inconsistent with simple monomer emission. We could then assume that, for $2 \mathbf{c}$ and $2 \mathbf{k}-\mathbf{m}$, solid-state 
Table 2 Fitting parameters of solid-state fluorescence decays $\left(\tau_{\mathrm{i}}, A_{\mathrm{i}}, f_{\mathrm{i}}\right)$ for compounds $2 \mathrm{a}-\mathrm{d}, \mathrm{g}-\mathrm{h}, \mathrm{k}-\mathrm{m}$, recorded by the time-correlated single photon counting system (TCSPC) or by the laser flash photolysis spectrometer

\begin{tabular}{|c|c|c|c|c|c|c|c|c|c|c|}
\hline & $\lambda_{\mathrm{em}}{ }^{a}(\mathrm{~nm})$ & $\tau_{1}(\mathrm{~ns})$ & $\tau_{2}(\mathrm{~ns})$ & $\tau_{3}(\mathrm{~ns})$ & $\tau_{4}(\mathrm{~ns})$ & $A_{1}\left(\mathrm{f}_{1}^{b}\right)$ & $A_{2}\left(\mathrm{f}_{2}{ }^{b}\right)$ & $A_{3}\left(\mathrm{f}_{3}{ }^{b}\right)$ & $A_{4}\left(\mathrm{f}_{4}{ }^{b}\right)$ & $\chi_{\mathrm{r}}^{2 c}$ \\
\hline $2 \mathbf{a}^{d}$ & 410 & 1.3 & 2.3 & 10.4 & - & $0.47(0.32)$ & $0.52(0.65)$ & $0.01(0.03)$ & - & 1.13 \\
\hline \multirow[t]{2}{*}{$2 \mathbf{b}^{d}$} & 460 & 0.7 & 8.8 & 23.7 & - & $0.20(0.01)$ & $0.65(0.60)$ & $0.15(0.38)$ & - & 1.20 \\
\hline & 570 & 1.6 & 10.6 & 23.7 & & $-0.45(-0.04)$ & $1.06(0.57)$ & $0.39(0.47)$ & & 1.15 \\
\hline \multirow[t]{2}{*}{$2 c^{e}$} & 420 & 9 & 42 & - & - & $0.85(0.54)$ & $0.15(0.46)$ & - & - & - \\
\hline & 465 & 10 & 46 & & & $0.81(0.48)$ & $0.19(0.52)$ & & & \\
\hline & 465 & 0.3 & 2.2 & 7.2 & 24.8 & $-1.60(-0.06)$ & $2.17(0.57)$ & $0.38(0.34)$ & $0.05(0.15)$ & 1.11 \\
\hline & 520 & 0.3 & 2.2 & 7.2 & 24.8 & $-2.92(-0.06)$ & $3.05(0.46)$ & $0.73(0.36)$ & $0.15(0.25)$ & 1.08 \\
\hline $2 \mathrm{~g}^{d}$ & 415 & 0.15 & 0.7 & - & - & $0.98(0.89)$ & $0.02(0.11)$ & - & - & 1.08 \\
\hline \multirow[t]{3}{*}{$2 \mathbf{h}^{d}$} & 420 & 0.5 & 2.1 & 9.3 & 34.1 & $0.54(0.14)$ & $0.38(0.39)$ & $0.08(0.35)$ & $0.01(0.13)$ & 1.08 \\
\hline & 490 & 0.5 & 2.1 & 9.3 & 34.1 & $-1.14(-0.02)$ & $0.28(0.02)$ & $1.08(0.28)$ & $0.78(0.72)$ & 1.18 \\
\hline & 550 & 0.5 & 2.1 & 9.3 & 34.1 & $-2.23(-0.02)$ & $0.29(0.01)$ & $1.64(0.26)$ & $1.30(0.75)$ & 1.20 \\
\hline $2 \mathbf{m}^{d}$ & 540 & 0.3 & 1.8 & 7.7 & 19.6 & $0.44(0.03)$ & $0.27(0.12)$ & $0.18(0.35)$ & $0.10(0.49)$ & 1.09 \\
\hline
\end{tabular}

${ }^{a}$ Selected emission wavelength by means of a monochromator with a $50 \mathrm{~nm}$ bandwidth. ${ }^{b}$ Intensity fractions were calculated using the following equation: $f_{\mathrm{i}}=A_{\mathrm{i}} \tau_{\mathrm{i}} / \Sigma A_{\mathrm{j}} \tau_{\mathrm{j}} \cdot{ }^{c}$ Global $\chi_{\mathrm{r}}{ }^{2}$, obtained for a global analysis of the full set of fluorescence decay curves, calculated for TCSPC experiments. ${ }^{d}$ Recorded by the TCSPC system, $\lambda_{\text {exc }}=370 \mathrm{~nm} .{ }^{e}$ Recorded by the laser flash photolysis spectrometer, $\lambda_{\text {exc }}=355 \mathrm{~nm}$.
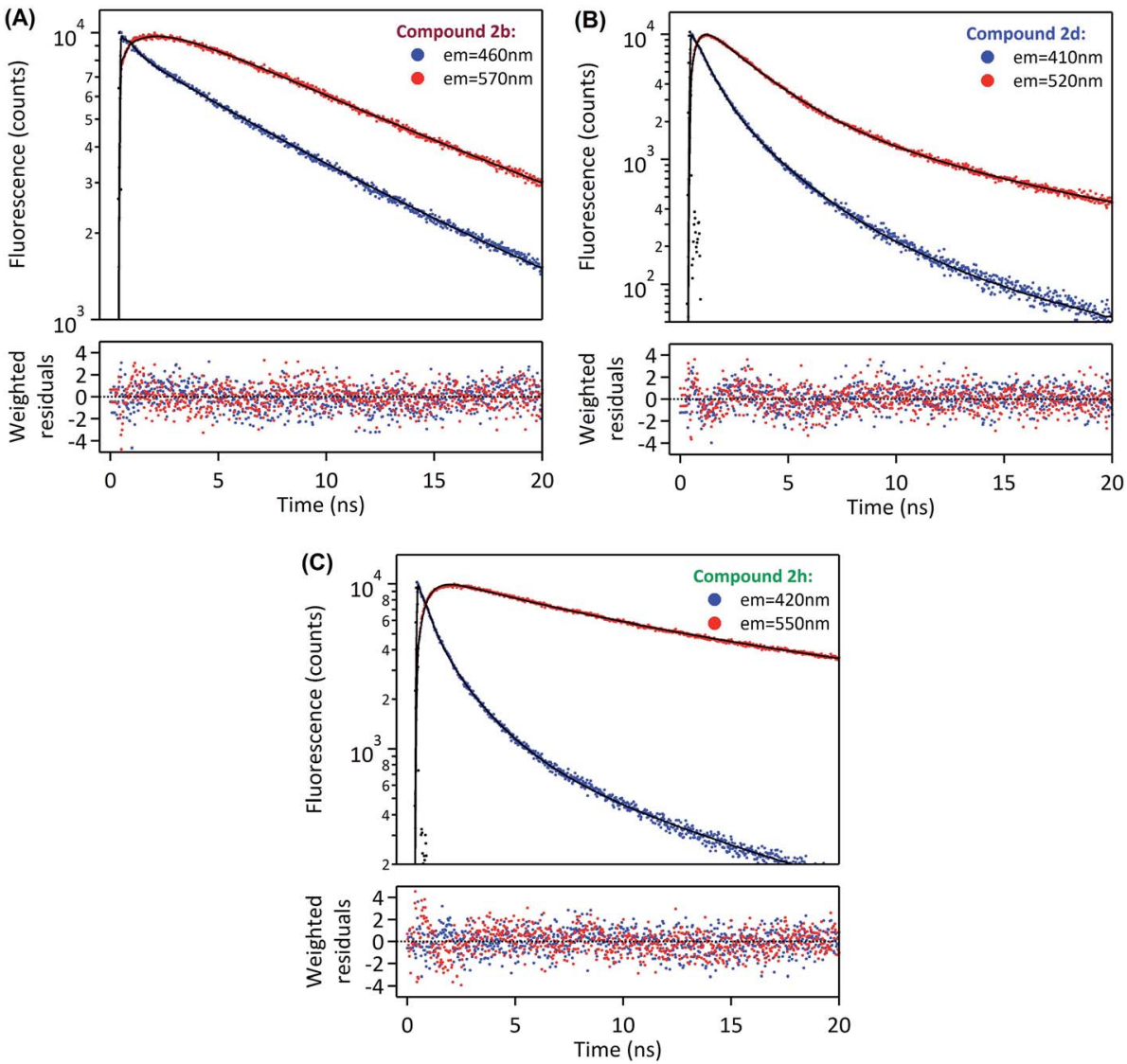

Fig. 5 Fluorescence decays of (A) 2b, (B) $2 \mathrm{~d},(\mathrm{C}) 2 \mathrm{~h}$ in the solid state, recorded by the TCSPC system at two different emission wavelengths: blue edge of the emission spectrum (blue dots) and red edge of the emission spectrum (red dots) ( $\lambda_{\text {exc }}=370 \mathrm{~nm}$ ). 
fluorescence arises from strongly emissive aggregates or dimers preformed in the ground state. Several populations of emitters may exist in the solid state, as is suggested by the multiexponential decays recorded for these compounds. It is worth noting that the situation of compounds $\mathbf{2} \mathbf{c}$ and $\mathbf{2 k}$ is quite unique, with extremely long decay components $\left(\tau_{1} \sim 10 \mathrm{~ns}\right.$ and $\tau_{2} \sim 45 \mathrm{~ns}$ for $2 \mathrm{c} ; \tau_{1} \sim 12 \mathrm{~ns}$ and $\tau_{2} \sim 70 \mathrm{~ns}$ for $2 \mathbf{k}$ ) associated with unprecedented high quantum yields (59\% and $62 \%$, respectively). Therefore, for these two derivatives we expect that the formation of aggregates in the crystalline structure and the specific $\pi-\pi$ interaction between pyrenyl groups are extremely favorable, thus leading to such effective solid-state fluorescence.

Solid-state excimer emission is a relatively common phenomenon for polycyclic aromatic compounds (including pyrene). ${ }^{40-42}$

\section{X-ray diffraction study of 2c}

We intended to compare molecular packings in the crystals of the synthesized amides but we were able to obtain crystals suitable for X-ray diffraction analysis only for $2 \mathrm{c}$. The compound crystallized in the space group $P 2_{1} / c$ of the monoclinic system after a long period of standing (2-3 weeks) in a concentrated solution in DMSO in an open tube (presumably moisture slowly diffused into the solution and decreased the solubility of $2 \mathbf{c}$ ). The molecular structure of $2 \mathrm{c}$ is shown in Fig. 6 .

The pyrenyl moiety is slightly bent, with the angle between the planes of rings C1-C2-C3-C4-C15-C14 and C7-C8-C9-C10-C11-C16 $\sim 4^{\circ}$. The amide group is twisted by 60.6(2) degrees from the average plane of the pyrenyl moiety. Together with the C1-C17 bond length greater than $1.5 \AA$ this suggests that there is only a very weak electronic conjugation between these units.

The crystallographic structure reveals that the molecules of 2c form $\pi$-stacked dimers with short $\mathrm{C} \cdots \mathrm{C}$ distances (Fig. 7), thus suggesting strong electronic interactions between the two pyrenyl moieties, which is in very good agreement with the photophysical investigations that were described and discussed in the previous section. This strong $\pi-\pi$ interaction in the ground state seems to be at the origin of the very high solid-

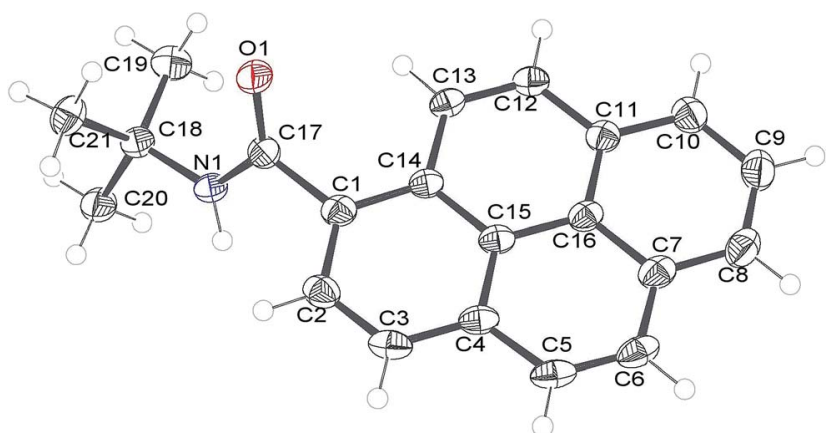

Fig. 6 Molecular structure of 2c (ORTEP representation). Displacement ellipsoids were drawn at 50\% probability level.

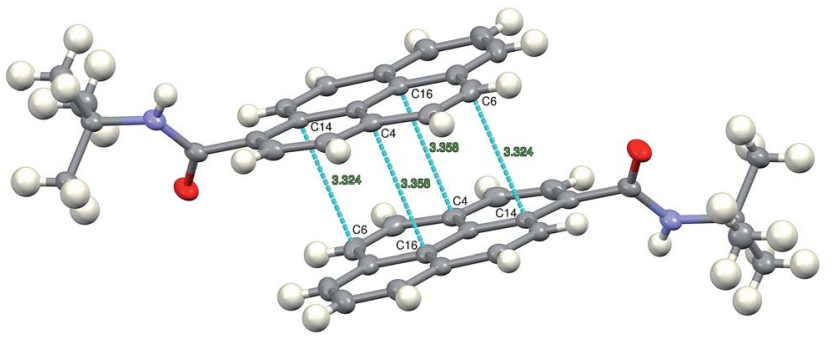

Fig. 7 Dimers of $\pi$-stacked molecules of $2 c$, related by the crystallographic center of symmetry.

state fluorescence quantum yield of the 2c derivative, which is associated with its very slow fluorescence decay.

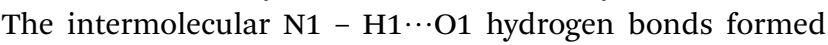
between the molecules packed along the crystallographic $c$ direction bring about the formation of infinite chains of $\mathrm{H}$ bonded molecules, with the $\mathrm{N} \cdots \mathrm{O}$ vector almost parallel to $c$ direction and adjacent pyrenyl moieties in the crystal structure located at an angle of 63.0(3) degrees (Fig. 8).

Crystal packing viewed along $\mathbf{b}$ direction confirms the formation of columns of $\pi$-stacked dimers of 2c. Along the crystallographic a direction the crystal structure is stabilized only by van-der Waals interactions of the tert-butyl moieties (Fig. 9).

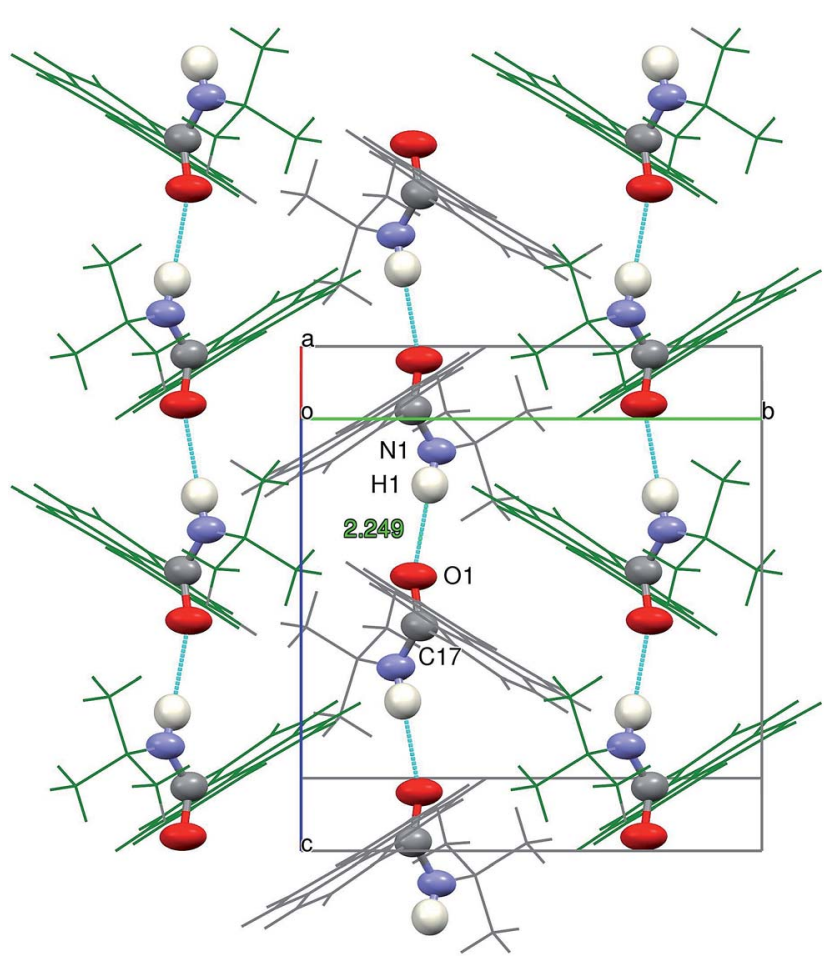

Fig. 8 View of the $\mathrm{N}-\mathrm{H} \cdots \mathrm{O}$ hydrogen bond in the context of crystal packing of $2 c$ along $a^{*}$ direction. The atoms directly involved in the $\mathrm{H}$-bond network are represented with thermal ellipsoids at 90\% probability level, to enhance the pattern. The remaining atoms are represented as wires in gray or in green in order to differentiate between the adjacent $\pi \cdots \pi$ interacting chains of $\mathrm{H}$-bonded atoms. 
(a)

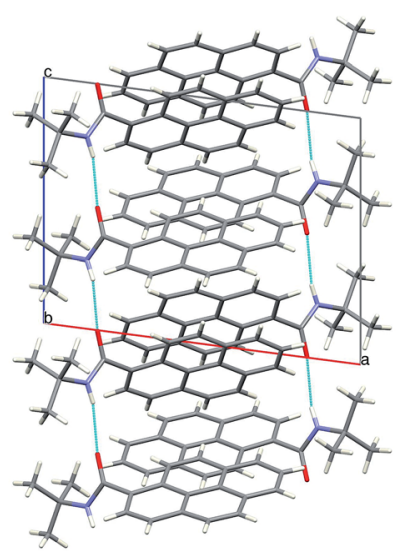

(b)

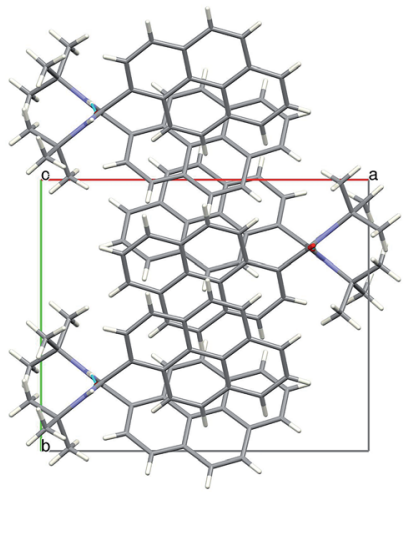

Fig. 9 Crystal packing of $2 c$ viewed along the crystallographic (a) $b$ axis (b) $\mathrm{C}$-axis. $\mathrm{H}$-bonds marked in cyan.

\section{Conclusion}

We have developed a simple and efficient synthetic route to primary and secondary pyrene-1-carbothioamides and carboxamides. The amides emit fluorescence in the solid state with quantum efficiencies up to $\sim 60 \%$. The primary amide in the solid state mainly displays structured monomer emission, whereas several secondary amides show a dynamic excimer formation leading to red-shifted emission. The strong solidstate fluorescence of the most efficient fluorophores, $\mathrm{N}$-tertbutyl- and $N$-(adamant-1-yl)pyrene-1-carboxamide can be attributed to preformed dimers or aggregates in the ground state, associated with very long decay times.

\section{Experimental}

Solvents were purified before use by reported methods. All reagents were purchased from Sigma-Aldrich and used without further purification. ${ }^{1} \mathrm{H}$ and ${ }^{13} \mathrm{C}$ NMR spectra were recorded in $\mathrm{CDCl}_{3}$ (if not indicated) or in DMSO- $d_{6}$ on a Bruker ARX 600 $\mathrm{MHz}\left(600 \mathrm{MHz}\right.$ for ${ }^{1} \mathrm{H}$ and $151 \mathrm{MHz}$ for ${ }^{13} \mathrm{C}$ ). Chemical shifts were referenced relative to solvent signals. Spectra were recorded at room temperature $(291 \mathrm{~K})$, chemical shifts are in ppm and coupling constants in Hz. IR spectra were run on an FT-IR Nexus spectrometer. Column chromatography was carried out on silica gel $60(0.040-0.063 \mathrm{~mm}, 230-400$ mesh, Fluka). Elemental analyses were performed at the Laboratory of Microanalysis in the Centre of Molecular and Macromolecular Studies in Łódź, Poland.

\section{Pyrene-1-carbothioamides 1a-j}

General procedure. KSCN (97 mg, $1 \mathrm{mmol}$ ) or isothiocyanate $(1.5 \mathrm{mmol})$ and $\mathrm{TfOH}(348 \mu \mathrm{l}, 4 \mathrm{mmol})$ were added to a solution of pyrene $(202 \mathrm{mg}, 1 \mathrm{mmol})$ in $\mathrm{CH}_{2} \mathrm{Cl}_{2}(10 \mathrm{ml})$ at room temperature. After stirring for $2 \mathrm{~h}$ the reaction mixture was poured into ice-water $(50 \mathrm{ml})$ and extracted several times with $\mathrm{CH}_{2} \mathrm{Cl}_{2}$. The combined extracts were dried over anhydrous

$\mathrm{Na}_{2} \mathrm{SO}_{4}$ and evaporated. Flash chromatography (silica gel/ $\mathrm{CH}_{2} \mathrm{Cl}_{2}$ ) afforded pure products.

1a. Yellow powder (165 mg, 63\%), m.p. $179-180{ }^{\circ} \mathrm{C} ;{ }^{1} \mathrm{H}$ NMR: $\delta 10.40(\mathrm{~s}, 1 \mathrm{H}), 9.93(\mathrm{~s}, 1 \mathrm{H}), 8.39(\mathrm{~d}, J=9 \mathrm{~Hz}, 1 \mathrm{H}), 8.32(\mathrm{t}, J=6.6$ $\mathrm{Hz}, 2 \mathrm{H}), 8.28$ (d, $J=6.6 \mathrm{~Hz}, 1 \mathrm{H}), 8.25$ (d, $J=9 \mathrm{~Hz}, 1 \mathrm{H}), 8.20$ (q, $J$ $=9 \mathrm{~Hz}, 2 \mathrm{H}), 8.10(\mathrm{t}, J=7.8 \mathrm{~Hz}, 1 \mathrm{H}), 8.02(\mathrm{~d}, J=7.8 \mathrm{~Hz}, 1 \mathrm{H}) ;{ }^{13} \mathrm{C}$ NMR: $\delta$ 202.76, 138.82, 130.77, 130.64, 130.22, 127.75, 127.11, 126.48, 125.60, 125.29, 125.18, 124.30, 124.15, 123.71, 123.60; IR $\left(\mathrm{cm}^{-1}\right)$ 3396, 3242, 3047, 1615, 1397, 1291, 914, $846 \mathrm{~cm}^{-1}$; anal. calcd for $\mathrm{C}_{17} \mathrm{H}_{11} \mathrm{NS}$ : C, 78.13; H, 4.24; N, 5.36; S, 12.27; found: C, 78.15; H, 4.22; N, 5.41\%.

1b. Yellow powder (291 mg, 96\%), m.p. 186.5-187 ${ }^{\circ} \mathrm{C} ;{ }^{1} \mathrm{H}$ NMR: $\delta 8.25-8.26(\mathrm{~m}, 1 \mathrm{H}), 8.18(\mathrm{t}, J=9.6 \mathrm{~Hz}, 2 \mathrm{H}), 8.05-8.09(\mathrm{~m}$, $3 \mathrm{H}), 7.99-8.02$ (m, 3H), 7.52 (s, 1H), 4.98-5.04 (m, 1H), 1.43 (d, J $=6.8 \mathrm{~Hz}, 6 \mathrm{H}),{ }^{13} \mathrm{C}$ NMR: $\delta$ 199.33, 138.72, 131.64, 131.23, 130.65, 128.53, 128.12, 127.10, 127.08, 126.26, 126.12, 125.73, 125.43, 124.64, 124.55, 124.51, 124.49, 123.49, 47.93, 21.37; IR (KBr) 3267, 3041, 2968, 2926, 1523, 1394, $849 \mathrm{~cm}^{-1}$; anal. calcd for $\mathrm{C}_{20} \mathrm{H}_{17} \mathrm{NS}$ : C, 79.17; H, 5.65; N, 4.62; S, 10.57; found: C, 79.15; H, 5.69; N, 4.66\%.

1c. Yellow powder (292 mg, 93\%), m.p.: $184-185{ }^{\circ} \mathrm{C} ;{ }^{1} \mathrm{H}$ NMR: $\delta 8.30(\mathrm{~d}, J=9 \mathrm{~Hz}, 1 \mathrm{H}), 8.19(\mathrm{t}, J=7.2 \mathrm{~Hz}, 2 \mathrm{H}), 8.13\left(\mathrm{dd}, J_{1}=2.4\right.$ $\left.\mathrm{Hz}, J_{2}=9.0 \mathrm{~Hz}, 2 \mathrm{H}\right), 8.08(\mathrm{~d}, J=9 \mathrm{~Hz}, 1 \mathrm{H}), 8.03\left(\mathrm{dd}, J_{1}=2.4 \mathrm{~Hz}\right.$, $\left.J_{2}=7.8 \mathrm{~Hz}, 2 \mathrm{H}\right), 8.01(\mathrm{~d}, J=9 \mathrm{~Hz}, 1 \mathrm{H}), 7.48(\mathrm{~s}, 1 \mathrm{H}), 1.79(\mathrm{~s}, 9 \mathrm{H})$; ${ }^{13} \mathrm{C}$ NMR: $\delta$ 200.23, 140.54, 131.44, 131.32, 130.74, 129.53, 128.59, 128.02, 127.16, 126.28, 125.79, 125.72, 125.39, 124.75, 124.64, 124.32, 123.54, 56.83, 27.87; IR (KBr): 3355, 3039, 2966, $1512,1400,1362,843 \mathrm{~cm}^{-1}$; anal. calcd for $\mathrm{C}_{21} \mathrm{H}_{19} \mathrm{NS}: \mathrm{C}, 79.45$; H, 6.03; N, 4.41; S, 10.10; found: C, 79.39; H, 6.07; S, 10.04\%.

1d. Yellow powder (314 mg, 91\%), m.p. $156-157{ }^{\circ} \mathrm{C} ;{ }^{1} \mathrm{H}$ NMR: $\delta 8.27(\mathrm{~d}, J=9 \mathrm{~Hz}, 1 \mathrm{H}), 8.20(\mathrm{~d}, J=7.8 \mathrm{~Hz}, 1 \mathrm{H}), 8.19(\mathrm{~d}, J=7.2$ $\mathrm{Hz}, 1 \mathrm{H}), 8.07-8.11(\mathrm{~m}, 3 \mathrm{H}), 8.01-8.03$ (m, 3H), 7.62 (s, 1H), 3.96 (t, $J=7.2 \mathrm{~Hz}, 1 \mathrm{H}), 3.95(\mathrm{t}, J=7.2 \mathrm{~Hz}, 1 \mathrm{H}), 1.8$ (kwintet, $J=7.4$ $\mathrm{Hz}, 2 \mathrm{H}), 1.44-1.48(\mathrm{~m}, 2 \mathrm{H}), 1.34-1.38(\mathrm{~m}, 4 \mathrm{H}), 0.93(\mathrm{t}, J=7.2 \mathrm{~Hz}$, $3 \mathrm{H}) ;{ }^{13} \mathrm{C}$ NMR: $\delta 200.70,138.76,131.74,131.29,130.72,128.53$, $128.21,127.14,126.31,126.29,125.78,125.47,124.69,124.65$, 124.57, 124.53, 123.71, 46.60, 31.42, 28.09, 26.78, 22.53, 13.96; IR (KBr) 3169, 3036, 2930, 1545, 1397, 1071, $847 \mathrm{~cm}^{-1}$. Anal. calcd for $\mathrm{C}_{23} \mathrm{H}_{23} \mathrm{NS}$ : C, 79.96; $\mathrm{H}, 6.71 ; \mathrm{N}, 4.05 ; \mathrm{S}, 9.28$; found: $\mathrm{C}$, 79.88; H, 6.70; N, 4.16\%.

1e. Yellow powder $(323 \mathrm{mg}, 94 \%)$, m.p.: $206-207{ }^{\circ} \mathrm{C} ;{ }^{1} \mathrm{H}$ NMR: $\delta 10.60(\mathrm{~d}, J=7.2 \mathrm{~Hz}, 1 \mathrm{H}), 8.32(\mathrm{~d}, J=9.6 \mathrm{~Hz}, 1 \mathrm{H}), 8.30(\mathrm{~d}, J=$ $10.8 \mathrm{~Hz}, 1 \mathrm{H}), 8.28(\mathrm{~d}, J=10.8 \mathrm{~Hz}, 1 \mathrm{H}), 8.17-8.23(\mathrm{~m}, 4 \mathrm{H}), 8.10(\mathrm{t}$, $J=7.8 \mathrm{~Hz}, 1 \mathrm{H}), 7.93(\mathrm{~d}, J=7.8 \mathrm{~Hz}, 1 \mathrm{H}), 4.62-4.64(\mathrm{~m}, 1 \mathrm{H}), 2.17$ $(\mathrm{d}, J=9.6 \mathrm{~Hz}, 2 \mathrm{H}), 1.83(\mathrm{~d}, J=12.6 \mathrm{~Hz}, 2 \mathrm{H}), 1.67(\mathrm{~d}, J=13.2 \mathrm{~Hz}$, 1H), 1.38-1.48 (m, 4H), 1.19-1.23 (m, 1H), ${ }^{13} \mathrm{C}$ NMR: $\delta$ 196.64, 139.09, 130.76, 130.47, 130.23, 127.81, 127.62, 127.11, 126.45, $125.55,125.23,124.46,124.31$, 123.99, 123.72, 123.63, 54.52, 30.60, 25.06, 24.56; IR (KBr) 3346, 2928, 2856, 1519, 1396, 845 $\mathrm{cm}^{-1}$; anal. calcd for $\mathrm{C}_{23} \mathrm{H}_{21} \mathrm{NS}: \mathrm{C}, 80.42 ; \mathrm{H}, 6.16 ; \mathrm{N}, 4.08 ; \mathrm{S}$, 9.34; found: C, 80.39; H, 6.22; N, 4.16\%.

1f. Yellow oil (285 mg, 78\%) ${ }^{1}$ H NMR: $\delta 13.25(\mathrm{~s}, 1 \mathrm{H}), 8.34(\mathrm{~d}, J$ $=7.8 \mathrm{~Hz}, 1 \mathrm{H}), 8.32(\mathrm{~d}, J=7.8 \mathrm{~Hz}, 1 \mathrm{H}), 8.29(\mathrm{~d}, J=7.8 \mathrm{~Hz}, 1 \mathrm{H})$, $8.28(\mathrm{~d}, J=9.6 \mathrm{~Hz}, 1 \mathrm{H}), 8.24(\mathrm{~d}, J=9.0 \mathrm{~Hz}, 1 \mathrm{H}), 8.21$ (d, $J=9.0$ $\mathrm{Hz}, 1 \mathrm{H}), 8.19$ (d, $J=7.2 \mathrm{~Hz}, 1 \mathrm{H}), 8.10$ (d, $J=7.2 \mathrm{~Hz}, 1 \mathrm{H}), 8.07$ (d, $J=7.8 \mathrm{~Hz}, 1 \mathrm{H}), 7.97(\mathrm{~d}, J=7.8 \mathrm{~Hz}, 2 \mathrm{H}), 7.66(\mathrm{t}, J=7.2 \mathrm{~Hz}, 1 \mathrm{H})$, $7.52(\mathrm{t}, J=7.8 \mathrm{~Hz}, 2 \mathrm{H}) ;{ }^{13} \mathrm{C}$ NMR: $\delta$ 197.49, 165.11, 139.58, 
137.97, 133.50, 133.31, 132.03, 130.99, 130.76, 130.08, 129.98, 129.06, 128.75, 128.44, 127.96, 127.18, 126.47, 125.85, 125.14, 124.97, 124.34, 123.35; IR (KBr) 1713, 1698, 1598, 1470, 1170, $846 \mathrm{~cm}^{-1}$; anal. calcd for $\mathrm{C}_{24} \mathrm{H}_{15} \mathrm{NOS}$ : C, 78.88; H, 4.14; N, 3.83; O, 4.38; S, 8.77; found: C, 79.03; H, 4.02; N, 3.97\%.

1g. Yellow powder $(287 \mathrm{mg}, 85 \%){ }^{1} \mathrm{H}$ NMR: $\delta 12.32(\mathrm{~s}, 1 \mathrm{H})$, $8.35(\mathrm{~d}, J=7.8 \mathrm{~Hz}, 1 \mathrm{H}), 8.34(\mathrm{~d}, J=7.8 \mathrm{~Hz}, 1 \mathrm{H}), 8.33(\mathrm{~d}, J=7.8$ $\mathrm{Hz}, 2 \mathrm{H}), 8.26$ (d, $J=9.0 \mathrm{~Hz}, 1 \mathrm{H}), 8.24$ (d, $J=3.6 \mathrm{~Hz}, 2 \mathrm{H}), 8.12$ (d, $J=7.8 \mathrm{~Hz}, 2 \mathrm{H}), 8.10$ (d, $J=7.8 \mathrm{~Hz}, 2 \mathrm{H}), 7.52(\mathrm{t}, J=7.8 \mathrm{~Hz}, 2 \mathrm{H})$, $7.35(\mathrm{t}, J=7.2 \mathrm{~Hz}, 1 \mathrm{H}) ;{ }^{13} \mathrm{C}$ NMR: $\delta$ 197.96, 139.73, 139.64, $130.79,130.23,128.62,128.45,128.15,127.85,127.13,126.53$, 126.38, 125.73, 125.57, 125.39, 124.70, 124.47, 123.94, 123.74, 123.68, 123.27, 123.24; IR (KBr) 3329, 3037, 1594, 1497, 1356, $846 \mathrm{~cm}^{-1}$; anal. calcd for $\mathrm{C}_{23} \mathrm{H}_{15} \mathrm{NS}$ : C, 81.87; H, 4.48; N, 4.15; S, 9.50; found: C, 81.84; H, 4.51; N, 4.26\%.

1h. Yellow powder (302 mg, 86\%), m.p.: $148-149{ }^{\circ} \mathrm{C},{ }^{1} \mathrm{H}$ NMR: $\delta 8.32(\mathrm{~d}, J=9.0 \mathrm{~Hz}, 1 \mathrm{H}), 8.19(\mathrm{~d}, J=12.2 \mathrm{~Hz}, 1 \mathrm{H}), 8.18(\mathrm{~d}, J=$ $12.2 \mathrm{~Hz}, 1 \mathrm{H}), 8.10(\mathrm{t}, J=7.8 \mathrm{~Hz}, 1 \mathrm{H}), 8.08(\mathrm{~d}, J=10.2 \mathrm{~Hz}, 1 \mathrm{H})$, $8.06(\mathrm{t}, J=7.8 \mathrm{~Hz}, 2 \mathrm{H}), 8.02(\mathrm{t}, J=7.8 \mathrm{~Hz}, 1 \mathrm{H}), 8.01(\mathrm{~d}, J=9.0 \mathrm{~Hz}$, $1 \mathrm{H}), 7.84(\mathrm{~s}, 1 \mathrm{H}), 8.02(\mathrm{~d}, J=7.8 \mathrm{~Hz}, 2 \mathrm{H}), 7.38-7.41(\mathrm{~m}, 2 \mathrm{H})$, 7.33-7.36 (m, 1H), 5.17 (d, $J=5.4 \mathrm{~Hz}, 2 \mathrm{H}) ;{ }^{13} \mathrm{C}$ NMR: $\delta 200.81$, 138.34, 136.04, 131.88, 131.28, 130.68, 129.06, 128.86, 128.63, $128.44,128.32,128.28,127.63,127.13,126.43,126.34,125.83$, 125.53, 124.71, 124.68, 124.53, 123.66, 50.81; IR (KBr) 3211, 3083, 3028, 1522, 1337, 1229, 948, $846 \mathrm{~cm}^{-1}$; anal. calcd for $\mathrm{C}_{24} \mathrm{H}_{17} \mathrm{NS}$ : C, 82.02; H, 4.88; N, 3.99; S, 9.12; found: C, 82.07; H, 4.85; N, 4.14\%.

1i. Yellow powder (323 mg, 88\%), m.p.: $189-190{ }^{\circ} \mathrm{C} ;{ }^{1} \mathrm{H}$ NMR: $\delta 12.19(\mathrm{~s}, 1 \mathrm{H}), 8.32-8.36(\mathrm{~m}, 3 \mathrm{H}), 8.30(\mathrm{~d}, J=9.0 \mathrm{~Hz}, 1 \mathrm{H}), 8.26$ $(\mathrm{d}, J=9.0 \mathrm{~Hz}, 1 \mathrm{H}), 8.22-8.24(\mathrm{~m}, 2 \mathrm{H}), 8.11(\mathrm{t}, J=7.8 \mathrm{~Hz}, 2 \mathrm{H})$, $8.00(\mathrm{~d}, J=9.0 \mathrm{~Hz}, 2 \mathrm{H}), 7.06(\mathrm{~d}, J=9.0 \mathrm{~Hz}, 2 \mathrm{H}), 3.83(\mathrm{~s}, 3 \mathrm{H}) ;{ }^{13} \mathrm{C}$ NMR: $\delta$ 196.87, 157.35, 139.70, 132.77, 130.79, 130.69, 130.24, 128.07, 127.79, 127.13, 126.51, 125.69, 125.60, 125.35, 124.89, 124.73, 124.69, 124.45, 124.02, 123.75, 123.69, 113.71, 55.30; IR (KBr) 3155, 3049, 2961, 1594, 1509, 1247, $849 \mathrm{~cm}^{-1}$; anal. calcd for $\mathrm{C}_{24} \mathrm{H}_{17} \mathrm{NOS}$ : C, 78.45; H, 4.66; N, 3.81; O, 4.35; S, 8.73; found: C, 78.37; H, 4.72; N, 3.95\%.

1j. Yellow oil (332 mg, 87\%), ${ }^{1} \mathrm{H}$ NMR: $\delta 12.77$ (s, 1H), 8.47 (d, $J=8.4 \mathrm{~Hz}, 2 \mathrm{H}), 8.36-8.40(\mathrm{~m}, 4 \mathrm{H}), 8.34(\mathrm{~d}, J=7.8 \mathrm{~Hz}, 1 \mathrm{H}), 8.24-$ $8.28(\mathrm{~m}, 4 \mathrm{H}), 8.15(\mathrm{~d}, J=7.8 \mathrm{~Hz}, 1 \mathrm{H}), 8.13(\mathrm{t}, J=7.2 \mathrm{~Hz}, 1 \mathrm{H}) ;{ }^{13} \mathrm{C}$ NMR: $\delta$ 199.86, 145.19, 144.27, 139.49, 131.07, 130.76, 130.16, 128.42, 128.11, 127.10, 126.62, 125.91, 125.62, 125.55, 124.87, 124.45, 123.73, 123.65, 123.62, 122.89; IR (KBr) 3299, 1595, 1551, 1498, 1332, 1317, 1303, 846, $\mathrm{cm}^{-1}$; anal. calcd for $\mathrm{C}_{23} \mathrm{H}_{14} \mathrm{~N}_{2} \mathrm{O}_{2} \mathrm{~S}$ : C, 72.23; H, 3.69; N, 7.33; O, 8.37; S, 8.38; found: C, 72.31; H, 3.59; N, 7.45\%.

\section{Pyrene-1-carboxamides 2a-i}

General procedure. Oxone ${ }^{\circledR}(1.5 \mathrm{mmol}$ in $10 \mathrm{ml}$ of water $)$ was added to the thioamides $1 \mathbf{a}-\mathbf{i}(1 \mathrm{mmol})$ dissolved in a mixture of acetonitrile $(30 \mathrm{ml})$ and water $(20 \mathrm{ml})$. The resulting solution was stirred at room temperature for $2 \mathrm{~h}$, poured into water $(100$ ml) and extracted several times with $\mathrm{CH}_{2} \mathrm{Cl}_{2}$. The organic phase was dried over anhydrous $\mathrm{Na}_{2} \mathrm{SO}_{4}$ and concentrated. The products were purified by silica gel column chromatography $\left(\mathrm{CH}_{2} \mathrm{Cl}_{2} / \mathrm{MeOH} 100: 0 \rightarrow 99: 1\right)$. 2a. White powder (210 mg, 86\%), m.p.: $257-258{ }^{\circ} \mathrm{C} ;{ }^{1} \mathrm{H}$ NMR $\left(\right.$ DMSO- $\left.d_{6}\right): \delta 8.63(\mathrm{~d}, J=9.6 \mathrm{~Hz}, 1 \mathrm{H}), 8.34(\mathrm{t}, J=9.0 \mathrm{~Hz}, 2 \mathrm{H}), 8.32$ $(\mathrm{d}, J=7.8 \mathrm{~Hz}, 1 \mathrm{H}), 8.30(\mathrm{~d}, J=7.8 \mathrm{~Hz}, 2 \mathrm{H}), 8.22(\mathrm{~d}, J=9.0 \mathrm{~Hz}$, $1 \mathrm{H}), 8.18(\mathrm{~d}, J=9.0 \mathrm{~Hz}, 1 \mathrm{H}), 8.16(\mathrm{~s}, 1 \mathrm{H}), 8.11(\mathrm{t}, J=7.8 \mathrm{~Hz}, 1 \mathrm{H})$, $7.73(\mathrm{~s}, 1 \mathrm{H}) ;{ }^{13} \mathrm{C}$ NMR (DMSO- $\left.d_{6}\right): \delta 170.86,131.76,131.55$, 130.66, 130.13, 128.17, 127.93, 127.72, 127.14, 126.46, 125.68, 125.48, 125.18, 124.80, 124.30, 123.81, 123.63; IR (KBr) 3339, $3169,1660,1622,1399,853 \mathrm{~cm}^{-1}$; anal. calcd for $\mathrm{C}_{17} \mathrm{H}_{11} \mathrm{NO}$ : C, 83.25; H, 4.52; N, 5.71; O, 6.52; found: C, 83.38; H, 4.67; N, $5.53 \%$.

2b. White powder $(273 \mathrm{mg}, 95 \%)$, m.p.: $211.5-212.5{ }^{\circ} \mathrm{C} ;{ }^{1} \mathrm{H}$ NMR (DMSO- $\left.d_{6}\right): \delta 8.55(\mathrm{~d}, J=7.8 \mathrm{~Hz}, 1 \mathrm{H}), 8.46(\mathrm{~d}, J=9.6 \mathrm{~Hz}$, $1 \mathrm{H}), 8.34(\mathrm{~d}, J=6.6 \mathrm{~Hz}, 2 \mathrm{H}), 8.31$ (d, $J=7.8 \mathrm{~Hz}, 1 \mathrm{H}), 8.25$ (d, $J=$ $9.0 \mathrm{~Hz}, 1 \mathrm{H}), 8.24(\mathrm{~d}, J=9.0 \mathrm{~Hz}, 1 \mathrm{H}), 8.21(\mathrm{~d}, J=9.0 \mathrm{~Hz}, 1 \mathrm{H}), 8.10$ $(\mathrm{t}, J=9.0 \mathrm{~Hz}, 2 \mathrm{H}), 4.26-4.31(\mathrm{~m}, 1 \mathrm{H}), 1.28(\mathrm{~d}, J=6.6 \mathrm{~Hz}, 6 \mathrm{H}) ;{ }^{13} \mathrm{C}$ NMR (DMSO- $d_{6}$ ): $\delta$ 167.91, 132.45, 131.32, 130.69, 130.17, 128.06, 127.94, 127.63, 127.15, 126.46, 125.64, 125.45, 125.10, 124.58, 124.29, 123.73, 123.64, 41.13, 22.35; IR (KBr) 3278, 3047, 2975, 1326, 1545, 1530, 1285, $846 \mathrm{~cm}^{-1}$; anal. calcd for $\mathrm{C}_{20} \mathrm{H}_{17} \mathrm{NO}$ : C, 83.59; H, 5.96; N, 4.87; O, 5.57; found: C, 83.49; H, $6.07 ; \mathrm{N}, 4.93 \%$.

2c. White powder (280 mg, 93\%), m.p.: $232-233{ }^{\circ} \mathrm{C} ;{ }^{1} \mathrm{H}$ NMR: $\delta 8.53(\mathrm{~d}, J=9 \mathrm{~Hz}, 1 \mathrm{H}), 8.22\left(\mathrm{dd}, J_{1}=2.4 \mathrm{~Hz}, J_{2}=10.0 \mathrm{~Hz}, 2 \mathrm{H}\right)$, $8.14(\mathrm{t}, J=7.8 \mathrm{~Hz}, 2 \mathrm{H}), 8.10(\mathrm{~d}, J=9 \mathrm{~Hz}, 1 \mathrm{H}), 8.05(\mathrm{~d}, J=7.8 \mathrm{~Hz}$, $1 \mathrm{H}), 8.03(\mathrm{t}, J=7.2 \mathrm{~Hz}, 2 \mathrm{H}), 5.95(\mathrm{~s}, 1 \mathrm{H}), 1.61(\mathrm{~s}, 9 \mathrm{H}) ;{ }^{13} \mathrm{C}$ NMR: $\delta$ $169.57,132.68,132.21,131.23,130.78,128.78,128.55,128.41$, 128.27, 127.15, 126.27, 125.69, 125.60, 124.80, 124.53, 124.38, 124.32, 52.29, 29.05; IR (KBr) 3325, 3046, 2977, 2958, 1639, 1523, 1298, 1223, $844 \mathrm{~cm}^{-1}$; anal. calcd for $\mathrm{C}_{21} \mathrm{H}_{19} \mathrm{NO}: \mathrm{C}, 83.69 ; \mathrm{H}$, 6.35; N, 4.65; O, 5.31; found: C, 83.76; H, 6.39; N, 4.53\%.

2d. White powder (316 mg, 96\%); ${ }^{1} \mathrm{H}$ NMR: $\delta 8.46(\mathrm{~d}, J=9.6$ $\mathrm{Hz}, 1 \mathrm{H}), 8.16$ (d, $J=7.8 \mathrm{~Hz}, 2 \mathrm{H}), 8.03-8.05$ (m, 2H), 7.99-8.02 (m, 2H), 7.93-7.96 (m, 2H), $6.29(\mathrm{~s}, 1 \mathrm{H}), 3.54(\mathrm{q}, J=7.2 \mathrm{~Hz}, 2 \mathrm{H})$, 1.67 (kwintet, $J=7.2 \mathrm{~Hz}, 2 \mathrm{H}), 1.40-1.44(\mathrm{~m}, 2 \mathrm{H}), 1.32-1.36$ (m, $4 \mathrm{H}), 0.92-0.94(\mathrm{~m}, 3 \mathrm{H}) ;{ }^{13} \mathrm{C}$ NMR: $\delta$ 169.92, 132.24, 131.36, $131.07,130.63,128.41,128.38,128.34,126.99,126.17,125.64$, $125.55,124.60,124.36,124.32$, 124.15, 123.70, 40.27, 31.49, 29.68, 26.70, 22.55, 13.99; IR (KBr) 3299, 3037, 2928, 1625, 1536, $848 \mathrm{~cm}^{-1}$; anal. calcd for $\mathrm{C}_{23} \mathrm{H}_{23} \mathrm{NO}$ : C, 83.85; H, 7.04; N, 4.25; O, 4.86; found: C, 83.89; H, 6.99; N, 4.31\%.

2e. White powder (298 mg, 91\%); m.p.: $236-237{ }^{\circ} \mathrm{C} ;{ }^{1} \mathrm{H}$ NMR: $\delta 8.52(\mathrm{~d}, J=9.0 \mathrm{~Hz}, 1 \mathrm{H}), 8.19(\mathrm{~d}, J=7.8 \mathrm{~Hz}, 2 \mathrm{H}), 8.11(\mathrm{~d}, J=9.0$ $\mathrm{Hz}, 1 \mathrm{H}), 8.09$ (d, $J=7.8 \mathrm{~Hz}, 1 \mathrm{H}), 8.08$ (d, $J=9.0 \mathrm{~Hz}, 1 \mathrm{H}), 8.04$ (d, $J=7.8 \mathrm{~Hz}, 1 \mathrm{H}), 8.02(\mathrm{t}, J=7.8 \mathrm{~Hz}, 1 \mathrm{H}), 8.01(\mathrm{~d}, J=9.0 \mathrm{~Hz}, 1 \mathrm{H})$, $6.05(\mathrm{~d}, J=7.8 \mathrm{~Hz}, 1 \mathrm{H}), 4.15-4.21(\mathrm{~m}, 1 \mathrm{H}), 2.17-2.19(\mathrm{~m}, 2 \mathrm{H})$, $1.80\left(\mathrm{dt}, J_{1}=3.6 \mathrm{~Hz}, J_{2}=13.8 \mathrm{~Hz}, 2 \mathrm{H}\right), 1.69\left(\mathrm{dt}, J_{1}=3.6 \mathrm{~Hz}, J_{2}=\right.$ $13.2 \mathrm{~Hz}, 1 \mathrm{H}), 1.50\left(\mathrm{qt}, J_{1}=3.6 \mathrm{~Hz}, J_{2}=12.0 \mathrm{~Hz}, 2 \mathrm{H}\right), 1.33\left(\mathrm{qd}, J_{1}\right.$ $\left.=3.6 \mathrm{~Hz}, J_{2}=12.0 \mathrm{~Hz}, 2 \mathrm{H}\right), 1.23\left(\mathrm{qt}, J_{1}=3.6 \mathrm{~Hz}, J_{2}=12.2 \mathrm{~Hz}\right.$, $1 \mathrm{H}) ;{ }^{13} \mathrm{C}$ NMR: $\delta$ 169.10, 132.31, 131.66, 131.15, 130.70, 128.54, $128.44,128.36,127.08,126.31,126.24,125.69,125.60,124.72$, 124.42, 124.34, 124.26, 49.03, 33.28, 25.58, 24.93; IR (KBr) 3274, 3039, 2934, 2916, 1625, 1532, 1306, $848 \mathrm{~cm}^{-1}$; anal. calcd for $\mathrm{C}_{23} \mathrm{H}_{21} \mathrm{NO}$ : C, 84.37; H, 6.46; N, 4.28; O, 4.89; found: C, 84.30; H, $6.52 ; \mathrm{N}, 4.37 \%$.

2f. Yellow oil (311 mg, 89\%); ${ }^{1} \mathrm{H}$ NMR: $\delta 9.56$ (s, 1H), $\delta 88.58$ $(\mathrm{d}, J=9.0 \mathrm{~Hz}, 1 \mathrm{H}), 8.20$ (d, $J=7.2 \mathrm{~Hz}, 2 \mathrm{H}), 8.11$ (d, $J=10.2 \mathrm{~Hz}$, 
$2 \mathrm{H}), 8.08(\mathrm{~d}, J=9.0 \mathrm{~Hz}, 2 \mathrm{H}), 8.03(\mathrm{t}, J=7.8 \mathrm{~Hz}, 1 \mathrm{H}), 8.00(\mathrm{~d}, J=$ $8.4 \mathrm{~Hz}, 1 \mathrm{H}), 7.46(\mathrm{~d}, J=7.8 \mathrm{~Hz}, 2 \mathrm{H}), 7.39(\mathrm{t}, J=7.2 \mathrm{~Hz}, 2 \mathrm{H}), 7.32$ $(\mathrm{t}, J=7.8 \mathrm{~Hz}, 1 \mathrm{H}), 6.48(\mathrm{~s}, 1 \mathrm{H}), 4.80(\mathrm{~d}, J=5.4 \mathrm{~Hz}, 2 \mathrm{H}) ;{ }^{13} \mathrm{C}$ NMR: $\delta 169.77,138.25,132.45,131.07,130.67,130.61,128.79,128.57$, 128.56, 128.53, 128.03, 127.90, 127.59, 126.99, 126.22, 125.72, 125.64, 124.64, 124.39, 124.31, 124.29, 124.13, 44.29; IR (KBr) 3261, 1644, 1595, 1523, 1441, 1331, $845 \mathrm{~cm}^{-1}$; anal. calcd for $\mathrm{C}_{24} \mathrm{H}_{15} \mathrm{NO}_{2}$ : C, 82.50; H, 4.33; N, 4.01; O, 9.16; Found: C, 82.63; $\mathrm{H}, 4.45$; N, 3.92\%.

2g. Yellow powder (296 mg, 92\%), m.p.: $253-255{ }^{\circ} \mathrm{C} ;{ }^{1} \mathrm{H}$ NMR: $\delta 10.71(\mathrm{~s}, 1 \mathrm{H}), 8.48(\mathrm{~d}, J=9.6 \mathrm{~Hz}, 1 \mathrm{H}), 8.40(\mathrm{~d}, J=9.0 \mathrm{~Hz}, 1 \mathrm{H})$, $8.37(\mathrm{t}, J=7.8 \mathrm{~Hz}, 2 \mathrm{H}), 8.30$ (d, $J=7.8 \mathrm{~Hz}, 1 \mathrm{H}), 8.29$ (d, $J=7.8$ $\mathrm{Hz}, 1 \mathrm{H}), 8.28(\mathrm{t}, J=9.0 \mathrm{~Hz}, 2 \mathrm{H}), 8.14(\mathrm{t}, J=7.2 \mathrm{~Hz}, 1 \mathrm{H}), 7.88(\mathrm{~d}, J$ $=7.8 \mathrm{~Hz}, 2 \mathrm{H}), 8.41(\mathrm{t}, J=7.8 \mathrm{~Hz}, 2 \mathrm{H}), 7.16(\mathrm{t}, J=7.2 \mathrm{~Hz}, 1 \mathrm{H}) ;{ }^{13} \mathrm{C}$ NMR: $\delta$ 167.56, 139.37, 131.84, 131.76, 130.68, 130.15, 128.69, 128.43 , 128.39, 127.76, 127.15, 126.60, 125.90, 125.68, 125.30, 124.39, 124.30, 123.75, 123.69, 123.60, 119.86; IR (KBr) 3260, 3038, 1645, 1524, 1441, 1331, $845 \mathrm{~cm}^{-1}$; anal. calcd for $\mathrm{C}_{23} \mathrm{H}_{15} \mathrm{NO}: \mathrm{C}, 85.96 ; \mathrm{H}, 4.70 ; \mathrm{N}, 4.36$; O, 4.98; found: C, 85.88; H, 4.76; N, $4.42 \%$.

2h. Yellow powder (302 mg, 90\%), m.p.: $161-162{ }^{\circ} \mathrm{C} ;{ }^{1} \mathrm{H}$ NMR: $\delta 8.58(\mathrm{~d}, J=9.0 \mathrm{~Hz}, 1 \mathrm{H}), 8.20(\mathrm{~d}, J=7.2 \mathrm{~Hz}, 2 \mathrm{H}), 8.11(\mathrm{~d}, J=10.2$ $\mathrm{Hz}, 2 \mathrm{H}), 8.08$ (d, $J=9.0 \mathrm{~Hz}, 2 \mathrm{H}), 8.03$ (t, $J=7.8 \mathrm{~Hz}, 1 \mathrm{H}), 8.00$ (d, $J=8.4 \mathrm{~Hz}, 1 \mathrm{H}), 7.46$ (d, $J=7.8 \mathrm{~Hz}, 2 \mathrm{H}), 7.39$ (t, $J=7.2 \mathrm{~Hz}, 2 \mathrm{H})$, $7.32(\mathrm{t}, J=7.8 \mathrm{~Hz}, 1 \mathrm{H}), 6.48(\mathrm{~s}, 1 \mathrm{H}), 4.80(\mathrm{~d}, J=5.4 \mathrm{~Hz}, 2 \mathrm{H}) ;{ }^{13} \mathrm{C}$ NMR: $\delta$ 169.77, 138.25, 132.45, 131.07, 130.67, 130.61, 128.79, 128.57, 128.56, 128.53, 128.03, 127.90, 127.59, 126.99, 126.22, 125.72, 125.64, 124.64, 124.39, 124.31, 124.29, 124.13, 44.29; IR (KBr) 3270, 3030, 2920, 1632, 1529, 1290, $848 \mathrm{~cm}^{-1}$; anal. calcd for $\mathrm{C}_{24} \mathrm{H}_{17} \mathrm{NO}$ : C, 85.94; H, 5.11; N, 4.18; O, 4.77; found: C, 85.87; $\mathrm{H}, 5.09$; N, 4.25\%.

2i. White powder (316 mg, 90\%), m.p.: $251-252{ }^{\circ} \mathrm{C} ;{ }^{1} \mathrm{H}$ NMR: $\delta$ 10.69 (s, 1H), 8.51 (d, $J=9.0 \mathrm{~Hz}, 1 \mathrm{H}), 8.37$ (d, $J=9.8 \mathrm{~Hz}, 1 \mathrm{H})$, $8.36(\mathrm{t}, J=7.8 \mathrm{~Hz}, 2 \mathrm{H}), 8.28(\mathrm{~d}, J=9.0 \mathrm{~Hz}, 1 \mathrm{H}), 8.27(\mathrm{~d}, J=9.0$ $\mathrm{Hz}, 1 \mathrm{H}), 8.25$ (t, $J=7.8 \mathrm{~Hz}, 2 \mathrm{H}), 8.12(\mathrm{t}, J=7.2 \mathrm{~Hz}, 1 \mathrm{H}), 7.83(\mathrm{~d}, J$ $=4.8 \mathrm{~Hz}, 2 \mathrm{H}), 6.99(\mathrm{~d}, J=4.8 \mathrm{~Hz}, 2 \mathrm{H}), 3.77(\mathrm{~s}, 3 \mathrm{H}) ;{ }^{13} \mathrm{C}$ NMR: $\delta$ $167.17,155.59,132.64,131.97,131.70,130.70,130.17,128.36$, 128.28, 127.82, 127.18, 126.57, 125.86, 125.64, 125.39, 124.46, 124.40, 123.79, 123.64, 121.50, 113.86, 55.23; IR (KBr) 3323, 3039, 2929, 1643, 1540, 1340, 1234, $848 \mathrm{~cm}^{-1}$; anal. calcd for $\mathrm{C}_{24} \mathrm{H}_{17} \mathrm{NO}_{2}$ : C, 82.03; H, 4.88; N, 3.99; O, 9.11; found: C, 82.05; $\mathrm{H}, 4.83$; N, 3.91\%.

2j. Yellow powder (289 mg, 79\%), ${ }^{1} \mathrm{H}$ NMR: $\delta 11.32(\mathrm{~s}, 1 \mathrm{H})$, $8.41(\mathrm{~d}, J=8.4 \mathrm{~Hz}, 1 \mathrm{H}), 8.40(\mathrm{~d}, J=7.8 \mathrm{~Hz}, 1 \mathrm{H}), 8.30-8.34(\mathrm{~m}$, $2 \mathrm{H}), 8.27(\mathrm{~d}, J=7.8 \mathrm{~Hz}, 1 \mathrm{H}), 8.26(\mathrm{~d}, J=9.0 \mathrm{~Hz}, 1 \mathrm{H}), 8.23(\mathrm{~d}, J=$ $9.0 \mathrm{~Hz}, 1 \mathrm{H}), 8.13(\mathrm{t}, J=7.8 \mathrm{~Hz}, 1 \mathrm{H}), 8.08(\mathrm{~d}, J=8.4 \mathrm{~Hz}, 1 \mathrm{H}), 7.86$ $(\mathrm{d}, J=8.4 \mathrm{~Hz}, 2 \mathrm{H}), 7.09(\mathrm{~d}, J=8.4 \mathrm{~Hz}, 2 \mathrm{H}){ }^{13} \mathrm{C}$ NMR: $\delta 168.15$, 142.69, 133.13, 130.52, 129.88, 129.51, 129.21, 128.32, 127.86, 127.12, 126.92, 126.59, 126.35, 124.78, 124.39, 123.64, 123.15, 122.58, 120.64; IR (KBr) 3172, 1612, 1594, 1514, 1336, 1029, 987, $841 \mathrm{~cm}^{-1}$; anal. calcd for $\mathrm{C}_{23} \mathrm{H}_{14} \mathrm{NO}_{3}$ : C, 75.40; $\mathrm{H}, 3.85 ; \mathrm{N}, 7.65$; O, 13.10; found: C, 75.51; H, 3.89; N, 12.89\%.

\section{Pyrene-1 carboxamides 2k-m}

General procedure. A solution of DCC (412 $\mathrm{mg}, 2 \mathrm{mmol})$ in $\mathrm{CH}_{2} \mathrm{Cl}_{2}(5 \mathrm{ml})$ was added to a solution of the pyrene-1-carboxylic acid (246 mg, $1 \mathrm{mmol}$ ) and amine (1.2 mmol) in $\mathrm{CH}_{2} \mathrm{Cl}_{2}(10 \mathrm{ml})$ and the mixture was stirred at $\mathrm{rt}$ for $24 \mathrm{~h}$. The resulting precipitate was filtered off. The solvent was evaporated and the residue chromatographed on silica gel using $\mathrm{CH}_{2} \mathrm{Cl}_{2}$ as eluent to afford the pure products.

2k. White powder (321 mg, 85\%). ${ }^{1} \mathrm{H}$ NMR: $\delta 8.33(\mathrm{~d}, J=7.2$ $\mathrm{Hz}, 1 \mathrm{H}), 8.32$ (d, $J=7.8 \mathrm{~Hz}, 1 \mathrm{H}), 8.26$ (d, $J=7.8 \mathrm{~Hz}, 1 \mathrm{H}), 8.22-$ $8.25(\mathrm{~m}, 3 \mathrm{H}), 8.19(\mathrm{t}, J=7.8 \mathrm{~Hz}, 2 \mathrm{H}), 7.89(\mathrm{~d}, J=7.8 \mathrm{~Hz}, 1 \mathrm{H})$, 1.63-1.83 (m, 6H), 1.24-1.34 (m, 3H), 0.69-1.11 (m, 6H); ${ }^{13} \mathrm{C}$ NMR: $\delta 167.92,131.83,131.10,130.59,130.18,128.02,127.67$, 127.18, 127.05, 126.43, 125.61, 125.44, 124.81, 124.63, 123.84, 123.48, 123.46, 48.81, 30.99, 30.47, 25.46; IR (KBr) 3306, 3039, 2929, 2855, 1644, 1541, 1339, $847 \mathrm{~cm}^{-1}$; anal. calcd for $\mathrm{C}_{27} \mathrm{H}_{25} \mathrm{NO}$ : C, 85.45; H, 6.64; N, 3.69; O, 4.22; found: C, 85.54; H, 6.59; N, 3.76\%.

2l. White powder (369 mg, 90\%). ${ }^{1} \mathrm{H}$ NMR (DMSO- $\left.d_{6}\right): \delta 9.69$ $(\mathrm{d}, J=8.4 \mathrm{~Hz}, 1 \mathrm{H}), 8.36(\mathrm{~d}, J=9.0 \mathrm{~Hz}, 1 \mathrm{H}), 8.35(\mathrm{~d}, J=7.2 \mathrm{~Hz}$, $1 \mathrm{H}), 8.33(\mathrm{~d}, J=7.8 \mathrm{~Hz}, 2 \mathrm{H}), 8.26(\mathrm{~d}, J=9.0 \mathrm{~Hz}, 1 \mathrm{H}), 8.23(\mathrm{~d}, J=$ $9.0 \mathrm{~Hz}, 1 \mathrm{H}), 8.22(\mathrm{~d}, J=9.6 \mathrm{~Hz}, 1 \mathrm{H}), 8.17(\mathrm{~d}, J=7.8 \mathrm{~Hz}, 1 \mathrm{H}), 8.12$ $(\mathrm{t}, J=7.2 \mathrm{~Hz}, 1 \mathrm{H}), 7.50(\mathrm{~d}, J=7.8 \mathrm{~Hz}, 4 \mathrm{H}), 7.41(\mathrm{t}, J=7.8 \mathrm{~Hz}$, $4 \mathrm{H}), 7.30(\mathrm{t}, J=7.2 \mathrm{~Hz}, 2 \mathrm{H}), 6.61(\mathrm{~d}, J=9.0 \mathrm{~Hz}, 1 \mathrm{H}) ;{ }^{13} \mathrm{C} \mathrm{NMR}$ $\left(\mathrm{DMSO}-d_{6}\right): \delta 168.21,131.68,131.52,130.62,130.11,128.36$, 128.20, 128.04, 127.80, 127.43, 127.12, 126.96, 126.48, 125.73, 125.52, 125.29, 124.36, 124.25, 123.69, 123.58, 56.55; IR (KBr) 3325, 3036, 2929, 1631, 1572, $848 \mathrm{~cm}^{-1}$; anal. calcd for $\mathrm{C}_{30} \mathrm{H}_{21} \mathrm{NO}$ : C, 87.56; H, 5.14; N, 3.40; O, 3.89; found: C, 87.45; H, 5.23 ; N, $3.43 \%$.

$2 m$. White powder (421 mg, 86\%), ${ }^{1} \mathrm{H}$ NMR (DMSO- $d_{6}$ ): $\delta 8.48$ $(\mathrm{d}, J=9.0 \mathrm{~Hz}, 1 \mathrm{H}), 8.34(\mathrm{~d}, J=7.8 \mathrm{~Hz}, 1 \mathrm{H}), 8.32(\mathrm{~d}, J=8.4 \mathrm{~Hz}$, $2 \mathrm{H}), 8.24-8.27$ (m, 3H), 8.19 (d, $J=8.4 \mathrm{~Hz}, 1 \mathrm{H}), 8.13$ (d, $J=7.8$ $\mathrm{Hz}, 1 \mathrm{H}), 8.11(\mathrm{~d}, J=8.4 \mathrm{~Hz}, 1 \mathrm{H}), 7.71-7.74(\mathrm{~m}, 6 \mathrm{H}), 7.50-7.52$ $(\mathrm{m}, 3 \mathrm{H}), 7.44-7.46(\mathrm{~m}, 6 \mathrm{H}) ;{ }^{13} \mathrm{C}$ NMR (150 MHz, DMSO): $\delta$ 173.01, 153.80, 148.66, 131.97, 131.83, 131.25, 130.84, 129.11, $128.50,128.19,128.14,127.96,127.93,127.88,127.33,127.16$, $126.71,126.57,126.47,125.97,125.87,124.70,124.52$, 124.51, 123.56, 122.67; IR (KBr) 3329, 2929, 2852, 1628, 1577, 1310, 847, $705 \mathrm{~cm}^{-1}$; anal. calcd for $\mathrm{C}_{36} \mathrm{H}_{25} \mathrm{NO}: \mathrm{C}, 88.68 ; \mathrm{H}, 5.17 ; \mathrm{N}, 2.87$; O, 3.28; found: C, 88.63 ; H, 5.13; N, 2.99\%.

\section{Acknowledgements}

Financial support from the National Science Centre Poland (NCN, Grant Harmonia UMO-2012/04/M/ST5/00712) is gratefully acknowledged.

\section{References}

1 T. M. Figueira-Duarte and K. Muellen, Chem. Rev., 2011, 111, 7260-7314.

2 G. Drummen, Molecules, 2012, 17, 14067-14090.

3 S. P. Sau and P. J. Hrdlicka, J. Org. Chem., 2012, 77, 5-16.

4 G. Bains, A. B. Patel and V. Narayanaswami, Molecules, 2011, 16, 7909-7935.

5 A. M. Breul, M. D. Hager and U. S. Schubert, Chem. Soc. Rev., 2013, 42, 5366-5407.

6 J. Zhao, W. Wu, J. Sun and S. Guo, Chem. Soc. Rev., 2013, 42, 5323-5351. 
7 M. E. Ostergaard and P. J. Hrdlicka, Chem. Soc. Rev., 2011, 40, 5771-5788.

8 A. Okamoto, Y. Saito and I. Saito, J. Photochem. Photobiol., C, 2005, 6, 108-122.

9 J. Xie, M. Ménand, S. Maisonneuve and R. Métivier, J. Org. Chem., 2007, 72, 5980-5985.

10 L. Zophel, V. Enkelmann and K. Mullen, Org. Lett., 2013, 15, 804-807.

11 J. M. Casas-Solvas, J. D. Howgego and A. P. Davis, Org. Biomol. Chem., 2014, 12, 212-232.

12 C. X. Yao, H. B. Kraatz and R. P. Steer, Photochem. Photobiol. Sci., 2005, 4, 191-199.

13 M. Ottonelli, M. Piccardo, D. Duce, S. Thea and G. Dellepiane, J. Phys. Chem. A, 2012, 116, 611-630.

14 Y. Niko, Y. Hiroshige, S. Kawauchi and G. I. Konishi, J. Org. Chem., 2012, 77, 3986-3996.

15 Y. Niko, Y. Hiroshige, S. Kawauchi and G. I. Konishi, Tetrahedron, 2012, 68, 6177-6185.

16 Y. Niko, Y. Cho, S. Kawauchi and G.-i. Konishi, RSC Adv., 2014, 4, 36480-36484.

17 Y. Niko and G. I. Konishi, Macromolecules, 2012, 45, 23272337.

18 F. Seela and S. A. Ingale, J. Org. Chem., 2010, 75, 284-295.

19 D. C. Knapp, J. D'Onofrio and J. W. Engels, Bioconjugate Chem., 2010, 21, 1043-1055.

20 S. Kodate, H. Wada, I. Suzuka, A. Okamoto, K. Tainaka, Y. Saito and I. Saito, Nucleic Acids Symp. Ser., 2004, 2006, 211-212.

21 S. T. Gaballah, Y. H. A. Hussein, N. Anderson, T. Q. T. Lian and T. L. Netzel, J. Phys. Chem. A, 2005, 109, 10832-10845.

22 A. Okamoto, K. Kanatani and I. Saito, J. Am. Chem. Soc., 2004, 126, 4820-4827.

23 J. Hwang, M. G. Choi, S. Eor and S.-K. Chang, Inorg. Chem., 2012, 51, 1634-1639.

24 S. Eor, J. Hwang, M. G. Choi and S.-K. Chang, Org. Lett., 2011, 13, 370-373.
25 S. P. Anthony, ChemPlusChem, 2012, 77, 518-531.

26 M. Shimizu and T. Hiyama, Chem.-Asian J., 2010, 5, 15161531.

27 Y. Hong, J. W. Y. Lam and B. Z. Tang, Chem. Commun., 2009, 4332-4353.

28 D. Plazuk, J. Zakrzewski, A. Rybarczyk-Pirek and S. Domagała, J. Organomet. Chem., 2005, 690, 4302-4308.

29 A. Wesolowska, L. Gros, S. Westerlich and T. S. Jagodzinski, ARKIVOC, 2008, 239-255.

30 T. Jagodzinski, Org. Prep. Proced. Int., 1990, 22, 755-760.

31 E. P. Papadopoulos, J. Org. Chem., 1976, 41, 962-965.

32 A. Wrona-Piotrowicz, D. Plazuk, S. Domagala and J. Zakrzewski, ARKIVOC, 2012, 412-420.

33 D. Plazuk, J. Zakrzewski, A. Rybarczyk-Pirek and S. Domagala, J. Organomet. Chem., 2005, 690, 4302-4308.

34 S. Aki, T. Fujioka, M. Ishigami and J.-i. Minamikawa, Bioorg. Med. Chem. Lett., 2002, 12, 2317-2320.

35 A. Corsaro and V. Pistara, Tetrahedron, 1998, 54, 1502715062.

36 I. Mohammadpoor-Baltork, M. M. Sadeghi and K. Esmayilpour, Phosphorus, Sulfur Silicon Relat. Elem., 2003, 178, 61-65.

37 I. Mohammadpoor-Baltork, M. M. Sadeghi and K. Esmayilpour, Synth. Commun., 2003, 33, 953-959.

38 N. S. S. Kumar, S. Varghese, C. H. Suresh, N. P. Rath and S. Das, J. Phys. Chem. C, 2009, 113, 11927-11935.

39 M. Zhu and C. Yang, Chem. Soc. Rev., 2013, 42, 4963-4976. 40 Z. Zhao, S. Chen, J. W. Y. Lam, Z. Wang, P. Lu, F. Mahtab, H. H. Y. Sung, I. D. Williams, Y. Ma, H. S. Kwok and B. Z. Tang, J. Mater. Chem., 2011, 21, 7210-7216.

41 R. Katoh, K. Suzuki, A. Furube, M. Kotani and K. Tokumaru, J. Phys. Chem. C, 2009, 113, 2961-2965.

42 T. Seko, K. Ogura, Y. Kawakami, H. Sugino, H. Toyotama and J. Tanaka, Chem. Phys. Lett., 1998, 291, 438-444. 